\title{
Feeling Modern: The History of Emotions in Urban
}

\author{
South Asia ${ }^{1}$
}

\section{ELIZABETH CHATTERJEE, SNEHA KRISHNAN AND MEGAN EATON ROBB}

The foundation of history's recent 'emotional turn' is that emotions matter in shaping individual and social motivations. Their importance is not just instrumental: against the explanatory grain of much scholarship since the nineteenth century, the history of emotions recognises that humans are not purely rational "economic subjects in trousers and skirts"- or, as it may be, dhotis and saris. $^{2}$

The emotional histories of this last group are only just beginning to be written. From its roots in the study of Europe, the history of emotions spread to the United States in the I980s, with its ascendancy overlapping with the rise of 'history from below'. By the beginning of the twenty-first century it had birthed a rich and fully-fledged research agenda, complete with dedicated institutes, journals and graduate courses. Yet, with a few notable exceptions, it has made limited inroads into global studies of South Asia, at least explicitly; a number of South Asianists have made valuable contributions to the subdiscipline avant la lettre, while a collective of contemporary scholars is forging a nascent agenda for the subcontinent. ${ }^{3}$ Nevertheless, the history of emotions remains "overwhelmingly a European and North American history", as a recent introduction noted. ${ }^{4}$

\footnotetext{
${ }^{1}$ We are grateful for the generous support from institutions across the University of Oxford - St John's College, The New College Ludwig Humanities Fund, All Souls College, the Oriental Institute, The Oxford Research Centre for the Humanities (TORCH), and Wolfson College - without which this special journal issue, long in germination, would not have been possible. The support of TORCH, All Souls College, and Wolfson College enabled us to host a preliminary conference on Urban South Asia in Oxford in 20I4; the results of this conference encouraged us to edit a special journal issue on the subject. St John's College, The New College Ludwig Humanities Fund, and the Oriental Institute supported a dedicated workshop for special issue contributors in Oxford in 20I6; the discussions held at this workshop contributed substantially to the quality of the final collection of articles.

${ }^{2}$ J. Bourke, Fear: A Cultural History (London, 2005), p. 289. On the emotions' scholarly sidelining in the nineteenth century, see W. I. Miller, The Anatomy of Disgust (Cambridge, MA, I997), p. xi; he attributes it to "the breaking off of a specialised discipline of psychology and psychiatry from moral philosophy, literature, and history".

${ }^{3}$ Especially notable is the work of Margrit Pernau, Razak Khan and their collaborators from the India Focus Group of the Centre for the History of Emotions at the Max Planck Institute for Human Development, Berlin. See, for example, the special issue on 'The Social Production of Space and Emotions in South Asia', (ed.) R. Khan, Journal of the Economic and Social History of the Orient 58 (2015).

${ }^{4}$ J. Plamper, The History of Emotions: An Introduction, translated by K. Tribe (Oxford, 2015), p. 64.
} 
What, then, can historians bring to the study of the emotions - a field that, while long dormant, is now rapidly expanding across multiple disciplines from neuroscience to philosophy and even economics? In his I94 I essay on emotional life and its historical study, Lucien Febvre notes that it is this social nature of emotions that makes them a viable subject for the historian. Writing of emotions as contagious, Febvre points to their political potential:

The emotions became a sort of institution. They were controlled in the same way as a ritual. Many of the ceremonies practised by primitive peoples are simulated situations with the obvious aim of arousing in all, by means of the same attitudes and gestures, one and the same emotion, welding them all together in a sort of superior individuality and preparing them all for the same action. $^{5}$

Three aspects stand out from this quotation. The first undergirds the entire history of emotions: the powerful thesis that emotions are not purely physiological, universal expressions of a generic Homo sapiens species in response to sensory information or simple corporal feelings (like hunger), nor are they a matter only of infinitely varied individual psychology. Of course, emotions are linked to biological responses (blushing), and ingrained habits and dispositions (irritability) in ways that undermine any sharp distinction between the 'conscious' and 'unconscious'. ${ }^{6}$ Yet they are not reducible to the evanescent viscera of sensation; they also involve an element of cognition and evaluative judgment. Such judgments are not made on a purely individual basis, however. Instead, historians treat emotions as fundamentally social: they are culturally produced and transmitted, and thus vary by place and over time. The same situations and spaces can produce divergent emotions in different people, yet these responses are culturally constructed, historically situated, and imbued with relations of power.

This brings us to a second notable feature of Febvre's discussion: emotions act as a kind of social glue analogous to rituals or institutions, owing their influence to recurrent cultural practice. In sharing the performance of emotions, people come together and recognise each other as belonging to the same community. This approach is echoed in cultural history approaches to emotions. For Peter Gay, shared emotions (elicited, for example, through humour) cement community consciousness, while Pierre Bourdieu saw a shared emotional attitude towards the past as shaping the cultural terms of class. ${ }^{7}$

Putting Febvre's first and second theses together, then, writing the history of emotions challenges hoary old dichotomies begging to be toppled but nevertheless hegemonic: mind and body, inner and outer, 'reasons' and 'passions', expression and experience, norm and variation, fixity and transience, universalism and cultural relativism. The need for such a toppling is reinforced by the existence of indigenous South Asian theories of emotion in

\footnotetext{
${ }^{5}$ L. Febvre, "Sensibility and History: How to Reconstitute the Emotional Life of the Past", in A New Kind of History: From the Writings of Febvre, (ed.) P. Burke and translated by K. Folca (London, I973), p. I 5.

${ }^{6}$ Anthropologists have in any case long challenged the notion of any sharp divide between individual and more subconscious modes of cognition, crystallising in recent interest in, for example, the anthropology of dreams; see G. Ingram, "Dreaming", in Oxford Bibliographies: Anthropology (online, 2015), http://www.oxfordbibliographies.com/view/document/obo-9780I99766567/obo-9780I99766567-0I 20.xml (accessed 24 February 20I7).

${ }^{7}$ P. Gay, "The Bite of Wit", Proceedings of the American Philosophical Society I35, 3 (I99I), pp. 327-33I, and P. Gay, Education of the Senses: The Bourgeois Experience, Victoria to Freud, vol. I (New York and London, I984).
} 
which such Western binaries do not feature; the celebrated classical aesthetic theory of rasa ('taste', 'juice' or 'emotional flavour') conceives of no sharp mind-body gap, for example, while its later interpreters in bhakti devotional traditions took an emphatically relational view of emotions, distinguishing between different types of love according to the human relations (like mother-child) structuring them. ${ }^{8}$ Scholarship originating in or about South Asia, as we review below, has proven especially useful in offering insights into the practical and conceptual bridging role that emotions play between the individual and community, or agency and structure.

The challenge of moving beyond such binaries can be embraced using a varied palette of theoretical approaches, as the different articles within this collection demonstrate. On one side of the spectrum lie contributions which explore emotions as an outgrowth of more traditional intellectual history, emphasising the role of culturally inflected moral judgments over emotions' more instinctual or habitual sides. Eve Tignol and Faridah Zaman examine the complex and quite different ways in which nostalgia conditioned elite Muslim social imaginaries two generations apart-after the I857 Mutiny and in the first decades of the twentieth century respectively-while C. Ryan Perkins analyses how portrayals of London and Lucknow were used by the Urdu-language writer Abdul Halim Sharar (I860-I926) to critically examine the colonial metropole while transforming nostalgia into a site of colonial contestation and urban renewal.

It is not only works of political thought that can be mined, however: Sneha Krishnan examines the emotional resonances of gossip and rumour in the journals of the colonial educator Eleanor McDougall (I 873-I956). Each of these accounts suggests that such 'higher', self-reflexive emotions owe their resonance and ethical import to their embeddedness in personal and community narratives; as the anthropologist Andrew Beatty has argued, such an approach treats emotions as deeply entangled "in stories, plots, and pasts", most explicable in narrative contexts structured by particular experiences. ${ }^{9}$ In this way emotions are centrally implicated in ideas about history, the present, and the future.

On the other side are contributions that favour an approach to emotions as practice. As Monique Scheer explains, drawing on Bourdieu, the practice-theory approach treats emotions as circulated and relational, contextual, often dependent on habit, and embodied, in ways that blur distinctions between the individual and the social or the affective and the cognitive. ${ }^{10}$ First, this approach allows for an effective challenge to methodological individualism in the history of the emotions. Second, it emphasises that emotions are intrinsically physical, spatial, and embodied-felt, manifested, and practised through real human bodies themselves socially situated. Building on Bourdieu's concept of habitus, such an approach stresses the role of habit, disposition, and action in constituting emotional lives. In this vein, Megan Eaton Robb and Anna Stirr examine emotions in everyday settings over time, exploring respectively the emotional imaginaries of pardah nashin (veiled women) in

${ }^{8}$ O. M. Lynch, "The Social Construction of Emotion in India”, in Divine Passions: The Social Construction of Emotion in India, (ed.) O. M. Lynch (Berkeley, I990). See also S. Pollock, "Introduction: An Intellectual History of Rasa", in A Rasa Reader: Classical Indian Aesthetics, (ed.) and translation S. Pollock (New York, 20I6), pp. I-45.

${ }^{9}$ A. Beatty, "How Did It Feel for You? Emotion, Narrative, and the Limits of Ethnography", American Anthropologist I I2, 3 (20I0), pp. 432-433.

${ }^{10} \mathrm{M}$. Scheer, "Are Emotions a Kind of Practice (and Is That What Makes Them Have a History?) A Bourdieuian Approach to Understanding Emotion", History and Theory 5I (20I2), pp. I93-220. 
turn-of-the-century Shahjahanabad and of contemporary rural-to-urban migrants in Nepal. Turning to look at female performing artists in late-nineteenth-century North India, Richard David Williams, like Stirr, shows how embodied practices of singing, dancing and listening generate emotional responses. In these articles emotions are "something we do, not just have", enacted and performed through practices. ${ }^{11}$

Methodological limitations constrain the choice of theoretical approach, however; there are practical reasons why the emotional imaginaries of literate elites have hitherto been overrepresented in the historiography. Evidence of the bodily facets of emotional practice may be scarce, and the historian cannot rely on anachronistic extrapolation from their own experiences to decipher them. The stimuli that provoke emotion also extend well beyond the visual - "the privileged sense of the West"-into the world of sound, smell, touch and taste, each of which carries its own cultural valences and yet is typically only captured in the archival record at a remove. ${ }^{12}$ Moreover, scholars of South Asia often cannot simply replicate the methods and sources that have been most typically deployed in Europe and the United States. Textual sources have provided a mainstay of the history of emotions, from diaries and memoirs to etiquette guides. Yet South Asian archives (both visual and aural) are often differently preserved; traditions and modes of life writing are not comparable; and, of course, huge swathes of the population leave little trace in the written record. The problems of the archive raise questions: Whose emotions are excluded by the limitations of this record? As Williams asks of poetry and Robb of literary histories, how should we read literary sources for evidence on lived emotional experiences, given that they are conditioned by genre and other conventions? Work on the intellectual history of rasa, for example, has highlighted the structuring work that aesthetics performs not only with regard to literature but in shaping the emotions of poets and readers. ${ }^{13}$ Examining the period between I850 and I960 in particular, what is the relationship between 'colonial' and 'native' sources? How accurately can any source reflect the lived experience of emotions itself-perhaps especially in the overwhelming richness of the urban sensorium? And, as with Stirr's careful deployment of ethnographic evidence on later periods, how much should we assume emotions vary over time, and thus how relevant is the conversation between history and contemporary anthropology?

The history of emotions not only in South Asia, but more broadly, is necessarily polyphonic in its source materials. The articles below therefore range widely across sources, from more traditional texts-including poetry (Tignol), travel literature (Perkins), newspapers and letters (Zaman), quasi-fictional etiquette guides (Robb), and missionary gossip (Krishnan) - through to song lyrics (Williams) and recordings (Stirr). While studies of the emotional productions and responses of elite groups feature heavily, this polyphony enables the emotional landscapes of more marginal groups to be represented too: also visible here are Nepalese migrants, veiled pardah nashin, and anxious female students in Chennai. Meanwhile, the sensual and intensely personal aspects of the experiences this collection seeks to explore demands that vivid descriptions, and not just 'dry analysis', may

\footnotetext{
${ }^{11}$ Ibid, p. I94.

${ }^{12}$ P. Stoller, The Taste of Ethnographic Things: The Senses in Anthropology (Philadelphia, I989), p. 5.

${ }^{13}$ Pollock, "Introduction".
} 
be methodologically essential. ${ }^{14}$ Each of the articles attempts to capture something of this richness by allowing their interlocutors room to write, speak and sing.

A final feature of Febvre's discussion is striking in the (post)colonial context that forms the focus of this special issue: given the language of anthropology in his time, emotional categories of practice are linked with 'primitive peoples'. This link points to a long trend in how emotions have been valorised both temporally and spatially in the construction of 'modernity', both within the disciplines of history and anthropology and the wider colonial project in which they were implicated. ${ }^{15}$ The 'primitive' was not only a physically distant subject but temporally 'behind'. Indeed, this is what made the primitive such a compelling unit of study to anthropologists of the period; an assessment of primitive tribes fit neatly into a positivist, universalising narrative that culminated in the development of 'civilised' man. ${ }^{16}$ Not yet the sovereign individual subject who transcends his or her community, the primitive was thus conceived to exist in a state akin to emergent understandings of childhood-a metaphor widely used in the civilising mission of colonial rule in both Asia and Africa. ${ }^{17}$ In this context, as historians have shown, the evaluation of emotions and emotionality has shaped the terms of colonial rule and of modernity as an ongoing project. ${ }^{18}$

Each of Febvre's three strands is visible in the articles that make up this special issue: that emotions are irreducibly social, constitutive of group identities, and bound up with judgments about what it means to live a 'good' life in the face of 'modernity', judgments that may be simultaneously intellectual and embodied in intuitive 'gut feeling' or habit.

\section{Between the individual and the social}

The intrinsically social character of emotions is highlighted by the significant relationship between experience and expression, in articulating emotions to oneself as much as for others. As historians, we are often asked how phenomena as ostensibly individual, ephemeral and visceral as emotions can make their way into the archival record without losing something irretrievable in the process. ${ }^{19}$ Both historians and anthropologists have countered that emotions are inseparable from their mediation, recognised too by scholars of medicine

${ }^{14}$ Ibid, pp. 8-9; Beatty, "How Did It Feel for You?".

${ }^{15} \mathrm{~J}$. Fabian, Time and the Other: How Anthropology Makes its Object (New York, 20I4).

16“"The idea that, in order to understand what the so-called civilised people may have been before they reached their higher enlightenment, we ought to study savage tribes, such as we find them still at the present day, is perfectly just. It is the lesson which geology has taught us, applied to the stratification of the human race." M. Müller, "Is Fetishism a Primitive Form of Religion?”, in The Essential Max Müller: On Language, Mythology and Religion, (ed.) J. R. Stone (New York, 2002), p. I99.

${ }^{17}$ Historians of childhood have argued that proper social being in the late nineteenth century was in part defined through emotional management, marked both by the capacity to feel pain intensely and to respond to it in a measured manner. As Robin Bernstein notes, the allegedly 'hardened' character of black children in America came to stand as proof of their less than fully human subjectivity. R. Bernstein, Racial Innocence: Performing American Childhood from Slavery to Civil Rights (New York, 20 I I); C. Steedman, Strange Dislocations: Childhood and the Idea of Human Interiority, 1780-1930 (Cambridge, MA, I995).

${ }^{18}$ We develop this point below; see also M. Pernau et al. (eds.), Civilizing Emotions: Concepts in Nineteenth Century Asia and Europe (Oxford, 2015).

${ }^{19}$ At the extreme, Elaine Scarry famously argued that language was incapable of capturing the experience of physical pain; see The Body in Pain (New York \& Oxford, I985). 
in their calls for increasingly careful use of language to elicit accounts of pain. ${ }^{20}$ Consider the evocative image deployed by the prisoner of war in Stirr's article, who sings that out of fright his "body gains 36 grams". The use and proliferation of such imagery is crucial not only in transmitting a sense of the individual experience to others, but also in constituting emotional states for the experiencing individual — and even in the articulation of the individual self. ${ }^{21}$

The emphasis on language - which is fundamentally relational — shows that the distinction between the 'inner' and the 'outer', or the 'authentic' individual interior and the necessarily diluted social expression of individuality, is a red herring. Margrit Pernau has accordingly suggested that scholars ought to set aside relativistic worries about the experience-expression gap and simply conceive of "the creation of a feeling and its expression ... as taking place in a single movement, through a variety of media and through practices". ${ }^{22}$ The mediation between individual experience and expression is of secondary concern to the transmission of emotions between people. This pragmatic attitude is one taken up by the articles below, opening up a more interesting range of questions about historical emotions.

The ways in which emotions are mobilised, named, communicated and regulated ${ }^{23}$ are structured by, and in turn constitute, social and power relations. This is the premise of much existing South Asian scholarship. Written from the postcolonial margins, the underlying assumption is inevitably one of cultural difference and power asymmetries rather than presumed universalism, although there has also been significant work done on the transfers of emotion across the East-West divide. ${ }^{24}$ Even work on the so-called 'five basic emotions'those which appear most universally across humankind, notably happiness, sadness, disgust, anger and fear-has often focused on their more complex, social instantiations. Historians have researched modern panics and anxieties over group status, for example. ${ }^{25}$ Anger, too, has inspired a literature that links it with the politics of dispossession, from the 'angry young man' of Indian cinema ${ }^{26}$ to "the sense of psychic, and embodied, rage" that attends ethnic violence. ${ }^{27}$ Meanwhile, studies of the 'higher' emotions have flourished. Love's many dimensions have been explored by scholars of religion, classical poetry, cinema, social history, music and art history. ${ }^{28}$ Boredom, that most modern of emotions, has been probed by both

\footnotetext{
${ }^{20}$ See especially W. M. Reddy, The Navigation of Feeling: A Framework for the History of Emotions (Cambridge and New York, 200I), which argues for the importance of language in 'translating' fleeting and disaggregated emotional states into utterance or action; J. Bourke, The Story of Pain: From Prayer to Painkillers (Oxford and New York, 20I4).

${ }^{21}$ Plamper, History of Emotions.

${ }^{22}$ Pernau, "Mapping Emotions", p. 635.

${ }^{23}$ These four categories of analysis are set out in Scheer, "Are Emotions a Kind of Practice?"

${ }^{24}$ Guy N. A. Attewell has traced the transmission of 'hysteria' in medical practice across India, Persia, Greece, and the Arabian Peninsula/North Africa, for example; see Refiguring Unani Tibb: Plural Healing in Late Colonial India (New Delhi, 2007), pp. 225-237.

${ }^{25}$ C. Gupta, Sexuality, Obscenity, Community: Women, Muslims, and the Hindu Public in Colonial India (New Delhi, 2005). See also the evocative collection Sarai Reader o8: Fear (Delhi, 2010), http://sarai.net/sarai-reader-08-fear/ (accessed 24 February 2017).

${ }^{26}$ R. Mazumdar, Bombay Cinema: An Archive of the City (Minneapolis, 2007), pp. I-40; R. Majumdar, “"Anger and After": Mrinal Sen's Calcutta Trilogy as History', unpublished manuscript.

${ }^{27}$ A. Appadurai, Modernity at Large: Cultural Dimensions of Globalization (Minneapolis, 1996), p. I49. On the pervasive "politics of outrage'- the "righteous anger" lying "at the juncture between the moral and the emotional realm" - in South Asia, see A. Blom and N. Jaoul, "Introduction: the Moral and Affectual Dimension of Collective Action in South Asia”, SAMAJ: South Asia Multidisciplinary Academic Journal 2 (2008), https://samaj.revues.org/I9I 2 (accessed 24 February 20I7), quotations at p. 7.

${ }^{28}$ See, for example, the multidisciplinary chapters in Lynch (ed.), Divine Passions, and F. Orsini (ed.), Love in South Asia: A Cultural History (Cambridge and New York, 2006).
} 
historians of empire and contemporary geographers - as has its opposite, the ludic appeal of violence. ${ }^{29}$ That emotions can have dramatic political implications is made clear by a range of works on the sentiments attending group belonging and collective action, nowhere more obvious in the struggle to construct a banal nationalism of united India against provincial linguistic 'passions', indicating the ambiguity of the geographic referent to which deshbhakti (patriotism) refers. ${ }^{30}$

Yet emotions are far from static. They are shaped and reshaped by the process of their expression and, linked as they are to more transient affective states, can be fluid over time. For this reason, as the cultural studies theorist Sara Ahmed and the anthropologist Véronique Bénéi have suggested in their different ways, the study of emotions as practice leads itself to a processual understanding of identity as becoming rather than being a fixed or essentialised essence. ${ }^{31}$ In this way the history of emotions reminds us that the social body is ever in formation. Emotions are the site where national and socio-political boundaries come to be articulated, especially on the body, and where grand imperial-national narratives precariously meet local histories, specific narratives, and lived experiences. Through everyday bodily practices such as singing, school-children develop emotions - pride, happiness - linked to a sense of belonging to an Indian nation, just as through shared laughter and violence young men can forge an emotional connection ("an effervescent sensation of togetherness") to a political movement. ${ }^{32}$

This processual notion of social identity as social identification also opens up the possibility that individuals might move between multiple overlapping communities. The field of 'emotionology' developed in the I980s by Peter Stearns stressed the study of the popular 'emotional standards' that enjoy hegemony in particular cultures at particular times, into which individuals are socialised and institutions reflect and encourage. ${ }^{33}$ Other scholars instead emphasise the heterogeneity of personal experience and the importance of emotional code-switching. Barbara Rosenwein has influentially argued that each individual navigates between different 'emotional communities' and styles in everyday life, opening up a multiplicity of emotional modes that are obscured by a narrow focus only on dominant (or written) cultural prescriptions. ${ }^{34}$ This recognition of emotional pluralism has been extended by South Asianists, who challenge the "temporal primordiality of a self-contained subject", thinking instead about the ways that emotion as practice exists in a dialogic relationship with social norms. ${ }^{35}$ More provocatively, Saba Mahmood has challenged the hegemony of the

\footnotetext{
${ }^{29}$ On boredom, see J. A. Auerbach, "Imperial Boredom”, Common Knowledge I I, 2 (2005), pp. 283-305; C. Jeffrey, "Timepass: Youth, Class, and Time Among Unemployed Young Men in India", American Ethnologist 37, 3 (2010): pp. 465-48I; and C. Fuller, "Timepass and Boredom in Modern India”, Anthropology of This Century I (2OI I). On violence as fun, see O. Verkaaik, Migrants and Militants: Fun and Urban Violence in Pakistan (Princeton, 2004).

${ }^{30}$ See V. Bénéi, Schooling Passions: Nation, History, and Language in Contemporary Western India (Stanford, 2008); S. Ramaswamy, Passions of the Tongue: Language Devotion in Tamil India, 1891-1970 (Berkeley, 1997); and L. Mitchell, Language, Emotion, and Politics in South India: The Making of a Mother Tongue (Bloomington, 2009).

${ }^{31}$ S. Ahmed, "Collective Feelings: Or, the Impressions Left by Others", Theory, Culture E Society 2 I, 2 (2004), pp. 25-42; Bénéi, Schooling Passions, p. 3.

${ }^{32}$ Bénéi, Schooling Passions; Verkaaik, Migrants and Militants, p. I I 8.

${ }^{33}$ P. N. Stearns and C. Z. Stearns, "Emotionology: Clarifying the History of Emotions and Emotional Standards", American Historical Review 90, 4 (1985), pp. 8 I 3-836.

${ }^{34}$ B. H. Rosenwein, Emotional Communities in the Early Middle Ages (Ithaca, NY, 2006).

${ }^{35}$ Pernau, "Mapping Emotions", p. 635.
} 
concept of the "liberal self whose subjectivity emerges only in the act of resistance, arguing that apparent acquiescence with hegemonic emotional practices can also be productive and agentive. ${ }^{36}$

Such analyses attempt to straddle the dichotomies of structure and agency, the individual and the communal, and the complexity of identities and emotional attachments. The articles in this collection make visible this dialogic relationship between emotions and communities. They explore cases in which emotions are elicited through different media and emotional communities thereby forged, for example through newspapers (see Zaman on pan-Islamist sentiment), folksongs (Stirr on migrant identity), Urdu magazine and book publishing networks (Robb on literary-ethnographic accounts of pardah nashin), and the elegiac performances of the marsiyah as a forum for collective grief (Tignol on post-I857 Muslim trauma). Emotions thus provided resources to imagine or consolidate communities, and for individuals to make sense of their place within the social world.

Through studying emotions, this collection brings to light heterogeneities that challenge dominant assumptions, both in scholarship and in literary genres. Even when discussing the case of the elite Muslim ashraf, already perhaps the best explored of India's historical 'emotional communities', ${ }^{37}$ the collection reveals a striking emotional pluralism. Williams shows that aesthetic and ethical attitudes towards courtesans were more favourable into the colonial period than often supposed, for example, while Zaman explores roads not taken against the grain of both a nineteenth-century Muslim history often read as necessarily coloured by reactionary nostalgia and a twentieth-century history seen as an inevitable progression towards the state of Pakistan. Focusing particularly on the period roughly spanning I 850 and I950, these articles in their very different ways explore one overarching process of becoming: how the emotional lives of South Asians altered in response to the notion of 'modernity', an inescapably normative concept with both a temporal and a spatial dimension, in which the urban timescape played an iconic role.

\section{Modern emotions in the city}

'Modernity', like the related concept of civilisation, is both a temporal and a spatial construct, and this collection accordingly writes histories of the emotions which unite these two dimensions. Modernity amounts, notoriously, to a teleological narrative of world history'History' — with a purportedly singular and universal end-point. It therefore provides a sense of past, present and future laden with normative dichotomies-between the modern and its opposite, the premodern, backward, or primitive.

This well-established relationship between modernity and time also maps onto a set of relationships between modernity and space. Modernity aspires to ubiquity and universality; to that extent it is linked to the production of space abstracted from particularities, from the air-conditioned mall or multiplex to the metro train and airport. Yet its narrative of time also designates particular areas or types of space as more or less 'modern'. The temporal and the

\footnotetext{
${ }^{36}$ S. Mahmood, Politics of Piety: The Islamic Revival and the Feminist Subject (Princeton, 201 I).

${ }^{37}$ See, for example, M. Pernau, "Male Anger and Female Malice: Emotions in India-Muslim Advice Literature", History Compass ro, 2 (20I2), p. I I9; M. Pernau, Ashraf into Middle Classes: Muslims in Nineteenth-Century Delhi (New Delhi, 20I3); and Khan (ed.) "Social Production of Space".
} 
spatial are fused in such zones; as the achievement of modernity is always and everywhere a work in progress, it produces timescapes, narrative geographies in which its teleological chronology meets the physical world. In this context two such categories of timescape are especially relevant: the global imaginary of colonialism, and the city as the iconic location of modernity, if not of 'modern' emotionality.

First, as Febvre implied, the world-historical narrative of modernity is utterly inseparable from the regional geographies of colonialism. Even as it purports to be a blueprint of universal relevance, as many theorists have noted, the definition of modernity is inseparable from the peculiar, provincial histories of the Western societies where it haphazardly evolved. More than this, it depended on juxtaposition with Others deemed to be 'premodern'. The conceptual origins of modernity were inextricable from the age of European expansion into the New World, the Edenic 'emptiness' that encouraged a new stage-based account of human history, and increasing encounters with other societies deemed to be technologically inferior and therefore 'barbaric' if not actually 'primitive'. ${ }^{38}$ In the age of high imperialism this narrative was overlaid with a set of more fixed racialised hierarchies, but these always sat in tension with the notion that colonialism served an inexorable modernising world-historical logic: a mission civilisatrice in which modernity would be imparted to the premodern.

Managing the emotions played a central role in the ideological and ethical modernist vision. Colonialism of course did not invent the fusion of the emotional and the ethical nor the alignment of the moral valences accorded to different emotions with social hierarchies, which are often gendered, racialised or class-based. In the early modern period, for example, many Hindu textual traditions drew a gendered and caste-inflected hierarchy between detached, self-disciplined Brahmin men and the uncontrolled emotionality, especially lust, associated with women and lower castes. ${ }^{39}$ The so-called 'self-conscious' emotions of shame and humiliation were mobilised to bolster such social hierarchies, as political theorists and ethnographers have argued with particular reference to the caste system. ${ }^{40}$ Work on Islamic Mughals in the seventeenth century has considered the ways that physical environments cultivated 'emotional and spiritual refinement' among Mughal men, whose virtue was constructed not only through knowledge but through increasingly individuated modes of consumption. ${ }^{41}$

Such indigenous hierarchies were overlaid and partially superseded by those imported by British colonialists. For much of the modern era mainstream Western thought has drawn a dichotomy between (praiseworthy) rationality and the (dangerous) passions; the 'lower' emotions like fear and anger were depicted as especially socially inappropriate. Even the Romantic backlash preserved the dichotomy, by simply inverting it to venerate

\footnotetext{
${ }^{38} \mathrm{M}$. Adas, Machines as the Measure of Men: Science, Technology, and Ideologies of Western Dominance (Ithaca, NY, I989).

${ }^{39}$ Such traditions did not necessarily advise ascetic withdrawal from all emotionality. Figures within the nebulous bhakti movement drew a distinction between a neo-Platonic, self-annihilating 'good' love devoted towards spiritual ends (later intriguingly channelled into proto-nationalist deshbhakti) versus the 'bad' love associated with conjugality. Sixteenth- and seventeenth-century sources often accordingly drew schematic hierarchies of the emotions. We are grateful to Tyler Williams for this point.

${ }^{40} \mathrm{G}$. Guru (ed.), Humiliation: Claims and Context (New Delhi, 2009). For a more general analysis, see W. I. Miller, Humiliation: And Other Essays on Honor, Social Discomfort, and Violence (Ithaca, NY, I993).

${ }^{41}$ R. O'Hanlon, "Manliness and Imperial Service in Mughal North India", Journal of the Economic and Social History of the Orient 42, I (I999), p. 69.
} 
the passions over "pre-established codes of decision", in the words of Wordsworth. ${ }^{42}$ This polarity is mirrored in the early historiography of emotions: echoing the Weberian notion of disenchantment and bureaucratic rationalisation, Norbert Elias's The Civilizing Process influentially read Western history as "the history of increasing emotional restraint". ${ }^{43}$ Margrit Pernau and her collaborators have shown that emotional hierarchies indeed mapped onto high imperial notions of the hierarchy of nations. ${ }^{44}$ Colonial ideas of civilisation thus included a pedagogical project of mastering the 'passions' in order to cultivate 'good' emotions such as civic spirit or urban fellow feeling among respectable classes in North India. This pedagogical project at once aimed to unite the ethical and the emotional.

Within South Asian emotions scholarship on the nineteenth and early twentieth centuries, this emphasis on moral education - both in its own right and as a lens on changing ideas of the self-in-society - is today perhaps the dominant trend. A growing focus on the history not of 'Imperialism with a capital I', but of its smaller workings in Christian mission schools, teacher training colleges and the lives of Bible women, has revealed a zone of encounter and exchange in which emotions were central to an imaginary of collective moral transformation. ${ }^{45}$ This transformation was not merely imposed top-down, by colonial authorities, but it was swiftly grasped and transformed by vernacular paradigms: Mytheli Sreenivas has argued that new notions of emotionality and conjugal pleasure combined with a burgeoning print culture to redefine both female communities and selfhood for middle-class Tamil women in the early twentieth century. ${ }^{46}$ Like the following articles, such studies emphasise that transformed imaginaries of emotional life became a core component of emerging discourses of modernity and 'modern dispositions', both for the colonial authorities and new vernacular publics.

The second crucial timescape is the city; as Gyan Prakash writes, "If modernity is a Faustian bargain to unleash human potential and subdue nature to culture, then modern cities are its most forceful and enduring expressions". ${ }^{47}$ Cities — and urban spaces more generallyplayed both a practical and an iconic role in the emotional encounter with the West. South Asian towns and cities were the locus of cultural competition and conflict between local traditions great and small, and those of the new arrivals, as the following articles make clear. Ideologically, too, the urban was the modern: the narrative of modernisation prescribed a transformation from a traditional, rural society to an urban, industrial, secular one. As Leon Trotsky once declared, the history of capitalism is the history of the victory of town over country. This collection of articles therefore takes the South Asian city as a space deserving of special consideration: the (post)colonial city was at once the great hope for modernisation

\footnotetext{
${ }^{42}$ W. Wordsworth, "Advertisement for Lyrical Ballads, with a Few Other Poems", in Romanticism: An Anthology, (ed.) D. Wu (3rd edition, Oxford, 2006), p. 33 I.

${ }^{43}$ B. H. Rosenwein, "Worrying about Emotions in History", American Historical Review I07, 3 (2002), p. 827; N. Elias, The Civilizing Process, vol. 2 (Oxford and Cambridge, MA, I994 [I939]).

${ }^{44}$ Pernau et al (eds.), Civilizing Emotions.

${ }^{45}$ E. Kent, Converting Women: Gender and Christianity in Colonial South India (New York, 2004).

${ }^{46} \mathrm{M}$. Sreenivas, "Emotion, Identity, and the Female Subject: Tamil Women's Magazines in Colonial India, I 890-I940", Journal of Women's Studies I4, 4 (2003), pp. 59-82.

${ }^{47}$ G. Prakash, "Introduction", in The Spaces of the Modern City: Imaginaries, Politics, and Everyday Life, (eds.) G. Prakash and K. M. Kruse (Princeton, 2008), p. I.
} 
along universal lines, the dramatic representation of modernity's dark side, and a defiant index of failure to imitate the iconic cities of the West. ${ }^{48}$

Nonetheless, the relationship between the urban-modern and the emotions is a complicated and locally specific one. Raymond Williams famously observed that British Victorians continued to emotionally idealise the countryside, yet this cannot be extrapolated to the subcontinent (a point explored further below). ${ }^{49}$ The contributions to this special issue emphasise the particularly South Asian character of the relationships between emotions and the urban that they seek to analyse. In so doing they advance a broader 'urban turn' in South Asian studies, pushing forward its agenda by highlighting the material significance of private women's space in mapping urban public life (Robb, Krishnan, Williams), showing the lines between the rural-natural and urban to be blurred (Stirr, Robb), and reframing the ways that narrative and material culture are linked (Tignol, Williams).

The relationship between emotions and urban space was a dual one, at once concrete and abstract. Recent work exploring the link between emotions and space has thus observed that, far from being 'only additive' to a study of space, emotions are essential to understanding the ways that sense of place emerges, and cultural practice surrounding space in a particular, historicised context. ${ }^{50}$ It is through emotions that abstract and physical spaces are navigated, their meaning and connection to identity consolidated, and sense of community surrounding those emotions transmitted. Physical spaces themselves produce specific emotional responses; indeed they are often consciously designed to do so, implicitly interlinking aesthetics with ethical intuitions. Cities are in turn themselves mapped-a specific and meaningful moral geography produced from abstract space - through these emotional responses, which may nonetheless defy their designers' intentions. Human spaces are thus not merely physical; they are also symbolic, representational and linguistically mediated. The emotional encounter with the 'modern', incarnated within the city, was similarly dual, engaging with both its concrete trappings, from pre-colonial ruins to particular commodities, and its broader symbolic content.

The dual nature of space and place is clear in Tignol's examination of the I 863 poetic anthology The Lament for Delhi (Fughān-e Dehlī), which argues that the genre of shahr ashob underwent an underappreciated shift in the aftermath of I 857: it moved away from a focus on city-dwellers to the physical city. This materialist shift had both practical and symbolic dimensions. City buildings were exalted both as "concrete sites for Indo-Muslim cultural mourning", thanks to the Mughal court's increasing immobility, and "the core of the Mughal elites' identity" as the repository of formative 'cultural trauma'. For Perkins' interlocutors, the image of the global city is similarly double: in Abdul Halim Sharar's travel writing, London features as both a concrete place available for observation and an iconic entity through which the problems of contemporary Lucknow could be thrown into sharp relief. Both articles also reveal how these authors used aesthetics to inform ethical intuitions in

\footnotetext{
${ }^{48}$ Of course, studies of emotions and constructed, lived space should not be confined to the city. Indeed, recent work has stressed the need to look beyond large cities to the qasbah, the princely state, and migratory paths to give a fuller understanding of the link between emotions and space in the South Asian context; see Khan (ed.), "Social Production of Space". Here, though, we seek to emphasise the special link between modernity, the city, and the remaking of emotional imaginaries.

${ }^{49} \mathrm{R}$. Williams, The Country and the City (New York, I973).

${ }^{50}$ Khan, "Social Production", p. 6I4.
} 
their listener and readerships: buildings stood as visual instantiations of the (pre)modern, while recorded behaviours could be used to elicit both shame and pride.

If Tignol and Perkins' two articles explore the emotional resonances of public space, the imperial project of emotional civilisation preferred to confine emotionality to a rather narrower sphere. The colonial city was overlaid with a second spatial distinction, again infused with the temporal narrative of modernity: a dichotomy between the public and private. At least for the respectable middle classes, emotions and emotional attachments such as religiosity were to be confined largely to the private space of the household. By contrast, the public sphere was to be dominated by a curiously passionless civic spirit, devoid of ostentatious displays of emotionality. At times scholarly work on the postcolonial political sphere has come uncomfortably close to replicating this modernist hierarchy. Clifford Geertz famously lauded the "civil sentiments" of sanitised, "routine allegiance to a civil state" over the "primordial attachments" of blood and land that he associated with the postcolonial world. ${ }^{51}$ Against the notion of a genteel Habermasian public sphere, South Asia's imagined publics have often been similarly analysed as passionate, parochial mobs whose emotions are manipulated by political elites for their own ends. ${ }^{52}$ The temporal-spatial hierarchies of the emotions inherited from colonial worldviews have thus proved oddly resilient.

This public-private distinction was, of course, highly gendered. 'Respectable' women were already often spatially segregated in North India (a practice usefully historicised in Robb's article). This was increasingly reinforced by westernised ideals of emotional companionship which recast marriage as private and individualised, thus drawing "new boundaries around private and public life" for the urban middle classes. ${ }^{53}$ Disseminated through the burgeoning print media, such ideals tied emotionality to both domesticity and femininity. ${ }^{54}$ In the context of modernity women's spatial confinement to the private sphere came to take on a temporal inflection, too: Indian nationalism cast women and the household as the repositories of 'authentic' tradition, both bastions against colonial cultural dominance and vulnerable to assault from without. Once again, then, desirably 'modern' emotionality was expressed through overlapping new spatio-temporal imaginaries.

In this vein, three of the articles in this collection explore the practice of imagining the city through its women, a tradition which predated colonialism and yet whose contours and stakes were reshaped by it. Williams' exploration of attitudes towards dancing girls in the earlier colonial city challenges the assumption that there was anything inevitable about the dominance of colonial emotional and moral prescriptions about women's roles; the patrons and teachers he examines nimbly navigated between multiple emotional communities. By contrast, Robb's analysis of the literary ethnography Rusūm-i Dihli (I928) shows how emotional interactions with the urban spaces of the household, neighbourhood and market acted as the locus for women's modern self-fashioning. It focuses on a record of customs or rusūm that represented the world of the segregated women's household as an emotive

\footnotetext{
${ }^{51}$ C. Geertz, The Interpretation of Cultures (New York, I973), quotation at p. 260.

${ }^{52}$ The instrumentalist argument on elite manipulation of popular emotions is especially associated with Paul Brass; on communal violence in India in particular, see Theft of an Idol: Text and Context in the Representation of Collective Violence (Princeton, 1997) and The Production of Hindu-Muslim Violence in Contemporary India (Seattle, 2003).

${ }^{53}$ Sreenivas, 'Emotion, Identity', p. 62.

${ }^{54}$ Ibid.
} 
sensorium linked to the city, rather than focusing on reformist critiques of the porous zenana and women's 'syncretic' rituals as previous reformist accounts had done. Meanwhile, Krishnan shows that the British missionary educator Eleanor McDougall developed an emotional geography of Madras (Chennai) structured by anxieties about disorder, sexual risk and racial difference. Each of these imaginaries was inextricably urban and spatial but in strikingly divergent modes, characterised by mobility between cities for Williams' Mughal courtesans yet by confinement and segregation for Robb and Krishnan's later interlocutors; this confinement was itself emotionally experienced in quite different fashions, conditioned by anxiety and risk for Krishnan's twentieth-century colonialist and linking emotion and urban consumption for Robb's pardah nashin women.

As is evident in these examples, emotional experiences of the city could often be the vehicle for moral education in juxtaposition to the notions of 'modernity' and 'civilisation' brought by the colonialists or reformists - but also for ethical and aesthetic alternatives. The colonial encounter appears in these accounts not as a monolithic or all-powerful referent but as a site of conflict, unevenness, and negotiation that varied over the century after i 850 . Its normative power rose after the I 857 Mutiny, but was increasingly contested in the wake of the burgeoning nationalist movement, the shock victory of an Asian power in the RussoJapanese War (1904-5), and the First World War, ${ }^{55}$ by the interwar period when Krishnan's missionary educator was writing, colonial anxiety about the limits of imperial power and knowledge was evident. Emotions thus become a site where we might explore postcolonial modernities, as Antoinette Burton put it, as an unfinished project. ${ }^{56}$

\section{Beyond modernity: nostalgia and other intrusions}

The relationship between the emotions and urban South Asia was not reducible to a mere appendage or imitation of patterns in the metropole, however. South Asia's cities did not all owe their origins to the British, nor were older vestiges and local particularities swept away by the colonial pedagogical project of emotional civilisation. Instead, the link between emotions and the city was inflected by pre-existing histories, traditions, and cultural values distinctive to the South Asian region. These emotional narratives are written in multiple tenses, compressing time and space so that, as in Perkins' Lucknow or Tignol's Shahjahanabad, glorious pasts, anxious presents, and uncertain futures appear simultaneously within the same urban timescapes.

Emotions, this collection shows, could prove a source for resistance to the colonial project of modernisation. In particular, the complex emotion labelled 'nostalgia' in English is revealed to be especially fertile, recurring in the articles by Tignol, Zaman, Stirr and Robb. Defined by Svetlana Boym in her seminal treatment as "a longing for a home that no longer exists or has never existed", it is an unmistakably historical emotion, especially visible at moments of societal rupture. ${ }^{57}$ As such it is bound up with modernity, Boym argues; indeed, nostalgia may even be modernity's emotional alter ego, marking as it does a "rebellion

\footnotetext{
${ }^{55}$ M. Pernau and H. Jordheim, "Introduction", in Civilizing Emotions, (eds.) Pernau et al., p. 6.

${ }^{56}$ A. Burton, "Introduction: The Unfinished Business of Colonial Modernities", in Gender, Sexuality and Colonial Modernities, (ed.) A. Burton (London and New York, I999), pp. I-I6.

${ }^{57}$ S. Boym, The Future of Nostalgia (New York, 200I), p. xiii.
} 
against the modern idea of time". More specifically, by interlocking individual emotions with collective biography nostalgia facilitates a particularist resistance to the universalist pretensions of the notion of progress and a unitary History. ${ }^{58}$

As even a cursory survey of the literature confirms, nostalgia is a strikingly persistent theme within South Asian scholarship, and the papers below demonstrate its resonances to be distinctively vernacular. British Victorian imperialists themselves preserved a curious emotional ambivalence about urbanisation. While in the colonial peripheries emotions were to be civilised and managed, especially among the urban middle-class natives who provided both the bulwark of the colonial ruling apparatus and the greatest perceived threat to its stability, at the metropole counter currents seriously challenged any link between urban areas and emotional-moral uplift. The city-or at least its working-class areas-was a place of lonely "dreadful delight", while the (lost) countryside was valorised an Edenic space of emotional openness, goodness and harmonious community. ${ }^{59}$ In the South Asian exemplars below, conversely, nostalgia is expressed not for a rural fantasy but for the precolonial city. In Tamil literature, for example, longing was expressed for Madurai over Madras, casting the former as the pinnacle of emotional and moral refinement while the latter was a rootless, amoral city entirely lacking in moral distinction. ${ }^{60}$ Other scholars have highlighted the importance of the small town, or qasbah, as an alternative ideal of progress to the city or a bastion against the city's corrupting influence. ${ }^{61}$ If the South Asian countryside was no refuge, then, nostalgia implied that colonialism had tainted the older city, formerly the heart of urbane civility and ethical discourse; it thus critiqued the link between the colonial city and modernity, even while the broader link between the urban and emotional civility was preserved.

Nostalgia "haunts histories of Indian Muslim cultural and social life" particularly after the decline and eventual dissolution of the Mughal Empire, as Zaman notes. In the face of crude popular treatments of the Muslim world as characterised by 'pathological nostalgia', though, the specific emotional resonances concealed beneath the concept are crucial to comprehend Muslim responses to colonial modernity. Boym draws an important distinction between 'restorative' and 'reflective' nostalgia: while the former seeks a return to a mythologised past, often homogenised and institutionalised within nationalist and religious revivalist movements, reflective nostalgia is more melancholic than return-oriented. ${ }^{62}$ Tignol's article accordingly probes nostalgia as an Urdu literary trope in the aftermath of the I 857 Uprising. Emotions were fostered not for their instrumental utility in fomenting anti-colonial resistance

\footnotetext{
${ }^{58}$ Ibid, pp. xv-xvi.

${ }^{59}$ Williams, Country and City; J. Walkowitz, City of Dreadful Delight: Narratives of Sexual Danger in Late-Victorian London (Chicago, I992). This would later find an echo among twentieth-century Indian nationalists, most notably M. K. Gandhi's praise of the village; his writings explicitly acknowledged his debt to western Romantics. Other nationalists were more ambivalent, as Jawaharlal Nehru's hopes for the high-modernist new city of Chandigarh suggest.

${ }^{60} \mathrm{~S}$. Ebeling, Colonizing the Realm of Words: The Transformation of Tamil Literature in Nineteenth-Century South India (Buffalo, 20Iо); A. R. Venkatachalapathy, “ 'Enna Prayocanam?' Constructing the Canon in Colonial Tamilnadu”, Indian Economic and Social History Review 42, 4 (2005), pp. 535-553.

${ }^{61}$ S. Mahmud, "Angāre and the Founding of the Progressive Writers' Association", Modern Asian Studies 30, 2 (I996), pp. 447-448; R. Rahman, Locale, Everyday Islam, and Modernity: Qasbah Towns and Muslim Life in Colonial India (New Delhi, 2015).

${ }^{62}$ Boym, Future of Nostalgia, p. xviii and passim.
} 
but for their intrinsic value within a Shia-influenced aesthetic of "collective commemoration and communal weeping". In this way the poetry she analyses offered an implicit critique of the colonial city through mournful contrasts with its dynamic and courtly antecedent.

In 'Beyond Nostalgia', Zaman cautions us still more strongly against misjudging Indian Muslim nostalgia as simply retrospective, oriented toward the past and forms of religious revivalism. Instead, she explores a mode of nostalgia as prospective, looking not backward against the current of 'History' but in some sense running perpendicular to it. Alongside the sacralisation of Delhi's physical environment that Tignol documents in the aftermath of I 857, Zaman argues that Muslim thinkers of the I9Ios and I920s, notably Mohamed Ali (I878-I93 I), were nostalgic not for the return of an Indian past but for a utopian notion of a far broader commonwealth: a pan-Islamic emotional community centred on the caliphate. The city was not necessarily equated with the preordained victory of the European-style nation-state, then, but with the troublingly non-national icon of the caliphate and the cities of the Bosphorus and the Holy Land. As the pan-Islamists themselves acknowledged, although this ideal purported to be rooted in history, it was a new invention that sought to reshape the future on a world-historical scale. Against the notion that nostalgia is inherently reactionary, Zaman thus suggests that in this case it "contained within it vast spatial and temporal potentialities".

In very different ways, Robb's examination of pardah nashin life-writing and Stirr's meditation on viraha ("longing and the pain of separation") also encourage us to re-evaluate linear, unitary ideas of modernisation and instead to understand nostalgia as productive. Robb's article touches on nostalgia for the women's household, whose distinctiveness as a segregated space had begun to dissolve during the reformist period. The contrast between the two examples of the rusūm genre central to the article- one penned by a prominent reformist, Syed Ahmed Dehlavi, and another by an anonymous pardah nashin woman, S. Begum Dehlavi-highlights the valorising power of nostalgia for the secluded women's household and the keys that sensory description held to producing that emotion. Nostalgia was crucial to the production and popularity of ethnographies of women's households, reflecting a fascination with the household of the secluded woman as reformist conversations threatened its segregated character. In this context, S. Begum Dehlavi's Rusūm-i Dihlī sidestepped hegemonic reformist narratives of women's households as porous and therefore corrupted by using patterns of consumption surrounding women's celebrations to map the civilised Shahjahanabad. Unlike the crude binary of 'the country and the city', however, this nostalgia did not simply demonise either but sought to productively combine both: women mapped the emotional city even as literary tropes simultaneously mapped their emotionality onto the natural, wild world.

Meanwhile, against the modernist teleology that reads the rural as irredeemably backward, Stirr movingly draws on acoustic evidence to demonstrate that the emotional linkages between rural and urban areas are far more nuanced and productive than this suggests, both in the historical past and the present. While the musical performance of viraha opens a rare window into the emotional practice/performance of the Gurkha prisoner during the First World War, for migrants in Nepal today similar performances help to build social ties of love and honour across the rural-urban divide. Emotions here are not only shaped by social power, but productive of social affiliations in their own right. Nostalgia features both as 
reflective lament and a statement of belonging. In the face of the homogenisation prescribed by modernity, whether in its incarnations of urbanisation or world war, it thus stands as a monument to the resilience of local eccentricities.

\section{Conclusion}

This special issue advances South Asian studies by building a more substantial bridge between the nascent 'emotional turn' and the better-established 'urban turn' in recent scholarship on South Asia. Its intention is to approach the South Asian city as both an archive of emotions, and as a timescape central to the region's grappling with modernity and the project of emotional cultivation that it prescribed. The articles in this collection represent a range of methodological approaches to a history of emotions, including practice theory ('doing emotions'), narrative as history, and intellectual histories of the emotions. In approaching the entity that we call 'South Asia', the articles in this collection also take a variety of approaches of scale: from Robb's study of a text that explores geographies of emotion within a kin network in Delhi to Perkins's contribution, which examines Lucknow's iteration as a global city, drawing comparisons to Paris and London.

Taken together, the articles in this special issue advance an understanding of the emotions that is grounded in histories of everyday life and simultaneously interlinked with contemporary intellectual movements and public debates. They show that emotions are meaningful because they materialise and shape social relations and political imaginaries. In nineteenth- and twentieth-century cities, where the conceit of South Asian modernity was arguably invented and circulated through a burgeoning print public and the emergent political and literary movements of the time, they show that a history of the emotions foregrounds the frictions that sustained these diverse iterations of the modern. In doing so, they advance an understanding of the South Asian city that brings the urban in dialogue - and tension-with the urbane.

While modernity in South Asia itself has been studied copiously, this special issue thus seeks to move the conversation forward by parsing out South Asian modernity's interlinked temporal and spatial dimensions: its teleological narrative towards a purportedly universal future that incorporates geographical hierarchies around regional backwardness and urban forwardness. The articles also unpick key supporting dichotomies, notably the public-versusprivate sphere distinction and its implication with gender relations. The history of emotions is central to deciphering these temporal-spatial elements, this collection argues, necessitating as it does a sensitivity to diachronic change, the importance of narrative, and a recognition of the intrinsically physical, embodied quality of emotional lives.

Writing a history of the emotions in South Asia means at once overleaping Orientalist stereotypes of the sentimental East and yet recognising the particularly South Asian character of the phenomena that they document. Here the articles reveal that, if the British typically fetishised 'the countryside' as the locus of emotional purity over the fetid city, many South Asians retained a more nuanced attitude to urbanism. The precolonial city or small-town qasbah were often deployed as iconic alternatives to the colonial city, places where civility and appropriate habits of mind flourished. This has only accelerated in scholarship on the 
more contemporary period, which has emphasised 'vernacular urbanisation' as much more than a deviation from a Western norm, a phenomenon in its own right. ${ }^{63}$

A focus on emotions also allows the historian — or the anthropologist, as the case may be-to critically probe how the past is made present: what, in other words, does a history of emotions in the late nineteenth and early twentieth centuries tell us about contemporary histories and regimes of emotional life in the post-colony? A provisional answer to this question might engage two closely related historical conversations to which the history of emotions contributes. First, feminist historians have for long critically interrogated the tacit narrative potential of historical archives. ${ }^{64}$ In Antoinette Burton's argument the archive is primarily a site of desire: however much 'History with a capital H' might disavow the temporal dramatic constructs that the archive invites, the pressures of narrative and desire shape the types of stories that historians tell. ${ }^{65}$ We read the archive for the stories that are most pressing to the contemporary moment. To this extent the writing of history is tinged with presentism and laden with emotions.

The multisensory archives of urban spaces in India certainly invite such probing for emotions, and in a way the essays in this volume are anticipated in the growing focus in anthropological and contemporary historical scholarship on the city as a site of rapid, almost unstoppable social transformation. Arjun Appadurai suggests that the city is rendered spectral by the sheer speed of change: the alternative histories of the urban that, now-felled old buildings and the cleared sites of former slums tell are not readily available for the taking. ${ }^{66}$ In accounts such as this, it is difficult not to read an echo of the nostalgic narratives that some of the articles in this volume explore. Modernity, as a substantial literature now proposes, has been closely associated with loss, and the multifaceted nostalgias explored here indicate what appears to be a widely-shared desire for a better time. According to the anthropologist Michael Jackson, the reason to bring the past and present to bear on each other is not only to draw causal relationships but to ask how each is invoked in the other. ${ }^{67}$ This sense of entangled times is especially evident in Zaman's paper in this volume, in which nostalgia is a site for an imaginary of the future. In the (post)colony, moreover, the longing for lost pasts and alternative futures amounts to an emotional challenge to modernity's universalising aspirations.

The second debate takes as its lens the intertwined material and emotional afterlives of colonial rule, and focuses on ruins. Writing on what she calls "imperial formations", Ann Laura Stoler posits that the postcolonial is not necessarily a time after but an afterlife of colonialism: a place where the enduring after effects of imperial rule and its socioeconomic regimes continue, if in uncanny ways. ${ }^{68}$ Colonial 'ruins' are not simply remnants to be regarded with the cosily wistful nostalgia of imperial sojourners and archaeologists

\footnotetext{
${ }^{63}$ On 'vernacular modernity' in postcolonial Bombay-Mumbai, for example, see T. B. Hansen, Wages of Violence: Naming and Identity in Postcolonial Bombay (Princeton, 200I).

${ }^{64}$ A. Burton (ed.), Archive Stories: Facts, Fictions and the Writing of History (Durham, NC, 2006).

${ }^{65}$ A. Burton, Dwelling in the Archive: Women Writing House, Home and History in Late Colonial India (Oxford and New York, 2003).

${ }^{66}$ A. Appadurai, "Spectral Housing and Urban Cleansing: Notes on Millennial Mumbai", Public Culture I2, 3 (2000), pp. 627-65I.

${ }^{67}$ M. Jackson, "Storytelling Events, Violence, and the Appearance of the Past", Anthropological Quarterly 78, 2 (2005), pp. 355-375.

${ }^{68}$ A. L. Stoler, 'The Rot Remains': From Ruins to Ruination”, in Imperial Debris: On Ruins and Ruination (ed.) A.L. Stoler (Durham, NC and London, 20I3).
} 
chronicling the physical vestiges of bygone civilisations, for this romantic nationalist view is "a mourning contingent and concomitant with what colonialisms destroy". ${ }^{69}$ Instead, ruins have material and often spectral afterlives that indicate the long temporality of imperialism, rendering colonial history a thing of the present. ${ }^{70}$ As we conclude this introduction, then, we might look forward to how the ruins of the period explored here-the century falling after 1850 - prompt a historicist reading of emotions in contemporary India.

Together these very different articles reveal fissures in the concept of nostalgia. If Tignol and Zaman explore the expansive potential of reflective nostalgia, then Robb and Stirr's articles gesture toward a less progressive politics. As the pardah nashin rue the disappearance of old-fashioned traditional shoe styles in the contemporary cityscape and Kathmandu's migrants pay to hear the folksongs of their rural childhoods, nostalgia becomes a consumer good. Love of the city and of community thus shades into sentimentalityand so, via consumption, into kitsch. The making of nostalgic spaces has been central to urban development projects in South Asian cities. ${ }^{71}$ The ruins that Tignol's poets lament have become tourist icons. Mary Hancock's research in Chennai shows that an influx of investments from diasporic South Asians has enabled local organisations to preserve and turn into museums old homes and administrative buildings that might have otherwise fallen to disrepair. If the circulation of imperial capital made ethnological museums of Indian villages, it would appear that a contemporary climate of anxiety about what scholars have called the 'vernacularisation' or 'decosmopolitanisation'72 of cities has resulted in the creative appropriation and revitalisation of landscapes that were falling into ruin: among them homes, parks and even, in Lahore, a famous brothel now turned into a restaurant. As the developmental state has stepped back in the wake of India's economic liberalisation, even the mills that formed the setting for classic urban histories of working class ferment in the I97os and $198 \mathrm{os}^{73}$ are now high-end bars that recreate grunge for the transnational upper-middle classes that frequent them. As the circulation of capital is transformed by changes beyond the scale of the individual city, then, social and economic institutions do not so much die out but endure in other forms - much like Appadurai's reading of the city, spectrally.

Yet this homogenising nostalgia has a darker side than commodification. In Milan Kundera's famously emotional formulation, "Kitsch causes two tears to flow in quick succession. The first tear says: How nice to see children running on the grass! The second tear says: How nice to be moved, together with all mankind, by children running on the grass!"74 The strange satisfaction of this "second tear" substitutes automatic, gut-level collective-feeling for ethical reflection, Kundera implies, validating rather than troubling collective norms. In this way, as Boym cautioned, nostalgia can bolster identity politics through exclusivist, monolithic visions of the past to be restored. ${ }^{75}$ Such monolithic visions have been central to debates on the writing and teaching of history in India-and of its

\footnotetext{
${ }^{69}$ Ibid, p. I6.

${ }^{70}$ On the Delhi sultanate and Mughal monuments, for example, see S. Kumar, "Qutb and Modern Memory", in his The Present in Delhi's Pasts (New Delhi, 2002), pp. I-6I.

${ }^{71} \mathrm{M}$. Hancock, The Politics of Heritage from Madras to Chennai (Bloomington, 2008).

${ }^{72}$ Appadurai, "Spectral Housing".

${ }^{73} \mathrm{R}$. Chandavarkar, History, Culture and the Indian City (Cambridge, 2009).

${ }^{74} \mathrm{M}$. Kundera, The Unbearable Lightness of Being, translated by M. H. Heim (New York, I984), p. 25 I.

${ }^{75}$ Boym, Future of Nostalgia.
} 
Californian diaspora-in recent times, most prominently with the rise of Hindu nationalist organisations such as the Shiv Sena and the Bharatiya Janata Party. ${ }^{76}$

Accordingly, ruins and spectral associations take on a more embattled quality when we consider some cities that this collection has not dealt with: places like Srinagar and Jaffna that years of communal and ethnic conflict have gradually worn down. These are places that do not usually feature in the imaginary of the South Asian city. Even less visible are the ephemeral cities that house refugee camps, religious festivals, and resettlement colonies, which come up, contribute to urban sprawl and disappear over the years. ${ }^{77}$ In Mike Masilamani's The Boy Who Speaks in Numbers, a children's book that uses dark whimsy to communicate the ineffable quality of civil war and violence in Sri Lanka, the refugee town where the eponymous Boy lives, Kettle Camp, is a "tin-pot kingdom" ${ }^{78}$ It is heating up rapidly, threatening to blow its lid off. It has none of what usually makes up the 'iconic' urban, but it certainly is not rural. And though officially 'temporary', no one in Kettle Camp is being resettled in a more permanent city anytime soon. We might wonder if, much like the former refugee colonies that now make up West Delhi, this too will be absorbed into the urban sprawl. Kettle Camp is a city that was born a ruin. Unlike more permanent settlements which have pasts that can be called on longingly and futures that can be looked to, here the past is ordinary life rendered monstrous by violence, and the future is an increasingly frustrating time of endless waiting. ${ }^{79}$ As Kettle Camp's name warns, the rigid nostalgic narrative of the postcolonial nation-state itself prompts an emotional backlash—and the emotions it collects might explode.

In historicising emotions in urban lives, then, we draw attention to the city as a site of compressed timescapes: an archive of the affective traces of what it has meant to dwell in modernity. The articles that comprise this special issue all hint at the multiplicity of emotional responses and resistances that this inspired. In this, they offer evidence of how scholarly sensitivity to the centrality of emotions contributes to the history of social life and modernity as a timescape, in which memory is not only an echo of the past, but a site for imaginaries of the future.liz.chatterjee@gmail.com,sneha.krishnan@sjc.ox.ac.uk,robbme@sas.upenn.edu

\author{
Elizabeth Chatterjee \\ University of Chicago \\ SNEHA Krishnan \\ St John's College, University of Oxford \\ Megan Eaton RobB \\ University of Pennsylvania
}

\footnotetext{
${ }^{76}$ R. Thapar, “The History Debate and School Textbooks in India: A Personal Memoir”, History Workshop Journal 67, I (2009), pp. 87-98.

${ }^{77}$ In their collection of essays on the Kumbh Mela, a festival that occurs once in twelve years, Rahul Mehrotra, Felipe Vera and Diana Eck argue that 'ephemeral cities' that are set up temporarily at times of crisis or to accommodate large crowds who gather for musical or religious gatherings are indeed an urban form. In this reading 'urban' is a category that is more capacious than 'city'. See R. Mehrotra and F. Vera (eds.), Kumbh Mela: Mapping the Ephemeral Megacity (Ostfildern, 2015).

${ }^{78}$ M. Masilamani, The Boy Who Speaks in Numbers (Chennai, 2015).

${ }^{79}$ Such endless times of waiting in sites of embattled life have been explored by anthropologists and historians of Latin America and Southern Africa; see, for instance, J. Livingston, Debility and the Moral Imagination in Botswana (Bloomington, 2005). On ordinary life rendered monstrous and pasts made ineffable by violence, see V. Das, Life and Words: Violence and the Descent into the Ordinary (Berkeley and Los Angeles, 2007).
} 